\title{
Measurement of Charged Particle Current Diffused from Vacuum Arc
}

\author{
Masamichi Furesawa Student Member (Saitama University) \\ Yasushi Yamano Member (Saitama University) \\ Shinichi Kobayashi Member (Saitama University)
}

Keywords : vacuum arc, charged particle current, oxygen-free copper electrode, $\mathrm{CuCr}$ electrode

\section{Introduction}

Particles diffused from vacuum arc can be used for thin film formation. Diffusion of particles from vacuum arc influences current breaking properties of a vacuum interrupter. For these application it is essential to clarify the behavior of particles diffused from vacuum arc at around current zero point. In this paper dependence of diffused charged particles current on the crest value of arc current before current interruption point was shown with a Faraday cup for oxygen-free copper electrodes and $\mathrm{CuCr}$ $(\mathrm{Cu}: \mathrm{Cr}=50: 50)$ electrodes.

\section{Experimental Setup and Methodology}

Figure 1 shows the experimental setup. Vacuum arc is generated by opening the test electrodes under current flowing. Two Faraday cups are used to measure the diffused charged particles from the vacuum arc. The distance from the appeared point of vacuum arc to them is $200 \mathrm{~mm}$. Bias voltages of $+30 \mathrm{~V}$ and $-100 \mathrm{~V}$ are applied to each Faraday cup to measure the ion current and electron current, respectively.

Test electrodes are made of oxygen-free copper or $\mathrm{CuCr}(\mathrm{Cu}$ : $\mathrm{Cr}=50: 50)$. The geometry of electrode is flat-plate type which diameter is $\varphi 25 \mathrm{~mm}$. Open speed of electrode is $0.8 \mathrm{~m} / \mathrm{s}$, and gap length after the electrode opened is $3 \mathrm{~mm}$.

Electron current and ion current diffused from vacuum arc of DC 100 A 150 A were measured. We also measured them under $\mathrm{AC}$ current flowing $(2,000 \mathrm{~A} \sim 10,000 \mathrm{~A})$ just before the current zero point.

\section{Experimental Result}

Figure 2 shows waveforms (arc current, arc voltage, ion current, electron current) when vacuum arc of DC 100 A 150 A was generated in case of oxygen-free copper electrodes. According to waveforms of charged particles current of Fig.2, diffused charged particles from vacuum arc enter into the Faraday cup with pulsive and intermittent states. This phenomenon corresponds to the

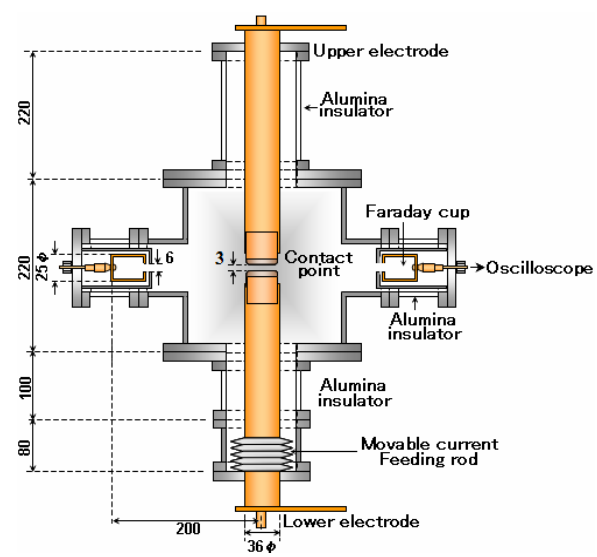

Fig. 1. Experimental setup

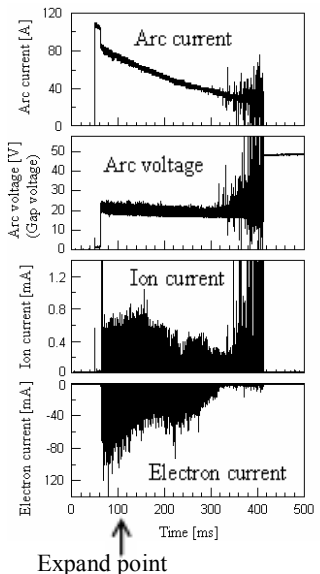

(a) Full scale

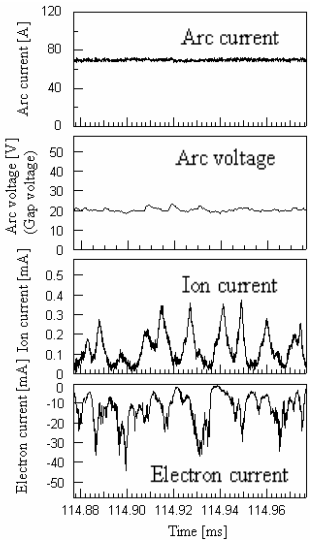

(b) Expand point
Fig. 2. Waveforms of arc current, arc voltage and charged particles currents

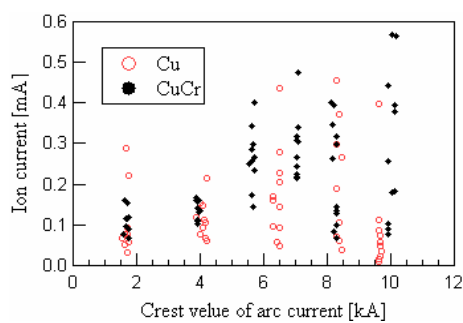

(a) Ion current

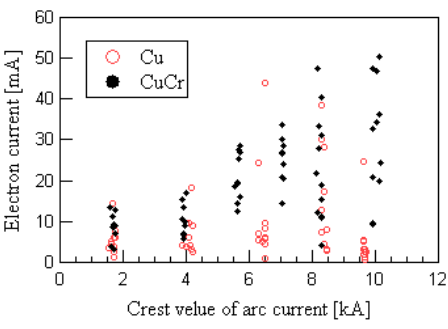

(b) Electron current

Fig. 3. Dependence of charged particle current on arc current

behavior of cathode spots. Electron current value is about 100 times as large as ion current value. The pulse width is about 1 10 $\mu \mathrm{s}$.

Figure 3 shows dependence of charged particle current just before current zero point when the crest value of arc current were 2,000 A 10,000 A in case of oxygen-free copper electrodes and $\mathrm{CuCr}(\mathrm{Cu}: \mathrm{Cr}=50: 50)$ electrodes. From Fig.3, experiments revealed that the amount of charged particle current for $\mathrm{CuCr}$ is larger than those for $\mathrm{Cu}$. 


\title{
電流零点前の真空アークから拡散する荷電粒子電流の測定

学生員 觸澤 将倫* 正 員 山納 康*
正 員 小林 信一*

論 文

\author{
Measurement of Charged Particle Current Diffused from Vacuum Arc \\ Masamichi Furesawa*, Student Member, Yasushi Yamano*, Member, Shinichi Kobayashi*, Member
}

\begin{abstract}
Particles diffused from vacuum arc can be used for thin film formation. Diffusion of particles from vacuum arc influences current breaking properties of a vacuum interrupter. For these application it is essential to clarify the behavior of particles diffused from vacuum arc at around current zero point. In this paper dependence of diffused charged particles current on the crest value of arc current before current interruption point was shown with Faraday cup in case of oxygen-free copper electrodes and $\mathrm{CuCr}(\mathrm{Cu}: \mathrm{Cr}=50: 50)$ electrodes. Experimental results were as follows. Ions and electrons diffused from vacuum arc entered into the Faraday cup with pulsive and intermittent states, when vacuum arc of DC 100 A 150 A was generated in case of oxygen-free copper electrodes. This phenomenon corresponds to the behavior of cathode spots. Electron current value was about 100 times as large as ion current value. The pulse width is about $1 \sim 10 \mu \mathrm{s}$. When the crest value of arc current were 2,000 A 10,000 A in case of oxygen-free copper electrodes and $\mathrm{CuCr}(\mathrm{Cu}: \mathrm{Cr}=50: 50)$ electrodes, the amount of charged particle current for $\mathrm{CuCr}$ before the current interruption point was larger than those for $\mathrm{Cu}$. The ratios of the ion current to the electron current diffused from vacuum arc were calculated by the waveforms of electron and ion currents. The current ratios of $0 \sim 0.02$ were taken when the crest value of arc current $2,000 \mathrm{~A} \sim 10,000 \mathrm{~A}$.
\end{abstract}

キーワード : 真空アーク，荷電粒子電流，無酸素銅電極， $\mathrm{CuCr}$ 電極

Keywords : vacuum arc, charged particle current, oxygen-free copper electrode, $\mathrm{CuCr}$ electrode

\section{1. はじめに}

真空アークは，放電プラズマ中のイオンを用いて薄膜形 成や表面改質などに利用されるなど，その高い拡散能力に より多くの分野に利用されている。また，真空遮断器にお いては，真空中でのアーク現象と真空の絶縁特性を利用し ており, 電流零点近傍でのアークの拡散と消滅, その後の 真空の絶縁回復によって電流を遮断している。これらの真 空アークを用いた応用技術において, 電流零点近傍の電極 間の様子は不明な部分が多い(1)。真空アークから拡散する荷 電粒子に関するデータはいくつか報告されているが(2), 電流 零点近傍の報告は少ない。真空アークの維持機構や真空中 における電流遮断現象を解明するための基礎データの一つ として, 電流零点前における真空アークから拡散する電子 やイオンの量を計測する必要があると考えられる。また, これらの荷電粒子の電流と電流遮断の失敗や成功の相関性 について調査することも興味深いと考えられる。

\footnotetext{
埼玉大学大学院理工学研究科

干338-8570 さいたま市桜区下大久保 255

Saitama University

255, Shimo-okubo, Sakura-ku, Saitama 338-8570
}

そこで, 本研究ではファラデーカップを用いた荷電粒子 の測定系を構築し, 供試電極材料として無酸素銅および $\mathrm{CuCr}$ (含有率 $\mathrm{Cu}: \mathrm{Cr}=50: 50$ ) の平行平板電極の場合につい て, 容器内圧力が $10^{-6} \mathrm{~Pa}$ 台の高真空に保たれた真空アーク 発生装置により直流小電流 (100 A 150 A) および交流大電 流 (波高值 : 2,000 A 10,000 A) の真空アークを発生させ, 真空アークから拡散する電子とイオンの同時測定を行っ た。また，荷電粒子の同時測定とともに高速度ビデオカメ ラで真空アークの挙動の観測を行った。交流大電流の荷電 粒子電流の測定においては, 真空アークから拡散する電子 とイオンの拡散量と, 電流零点前に流れる交流アーク電流 の波高值の大きさに対する依存性を調查した。

\section{2. 実験装置・方法}

〈2·1〉実験用真空チャンバと電極形状 Fig.1 に本研 究で使用した実験装置の概略図を示す。装置本体はセラミ ック絶縁筒およびステンレス鋼製真空容器から構成されて いる。その排気はロータリーポンプおよびターボ分子ポン プにより行っており, 容器内の圧力は実験前で $10^{-6} \mathrm{~Pa}$ 台の 高真空に保たれている。真空容器内には外部から大電流を 
通電させるための導体がチャンバの上下から導入されてお り，それら導体が真空中において突き合わせた形となって いる。接点電極は交換が可能な構造になっており，供試電 極材料として無酸素銅および $\mathrm{CuCr}$ (含有率 $\mathrm{Cu}: \mathrm{Cr}=50: 50)$ を 使用している。接点電極形状は Fig.2 に示すような直径 25 $\mathrm{mm}$ の平板電極を用いている。

実験用真空チャンバに電流を導入する導体は，上部導体 が真空容器にろう付けされた固定導体で, 下部導体がベロ ーズにより上下に可動できる構造となっている。上下の電 流導入導体の先端部に, 取り付けバンドにより供試電極を 固定している。電極の開閉動作は，空気シリンダーで行う。 空気シリンダーは下部導体底部に絶縁物を介して取り付け られており，コンプレッサからの圧縮空気を電磁弁により

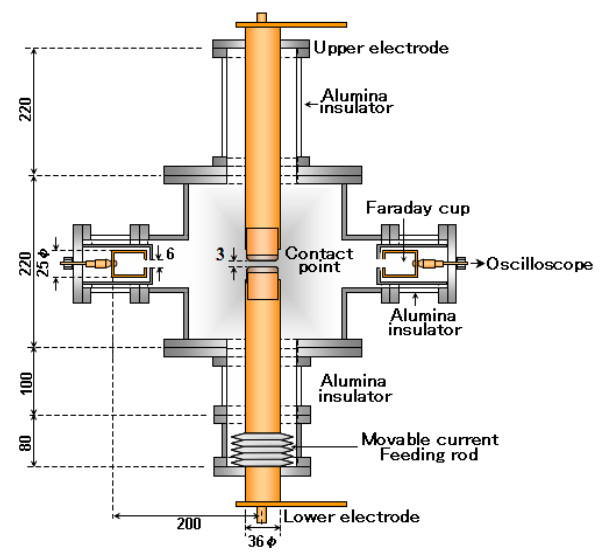

(a) Side view

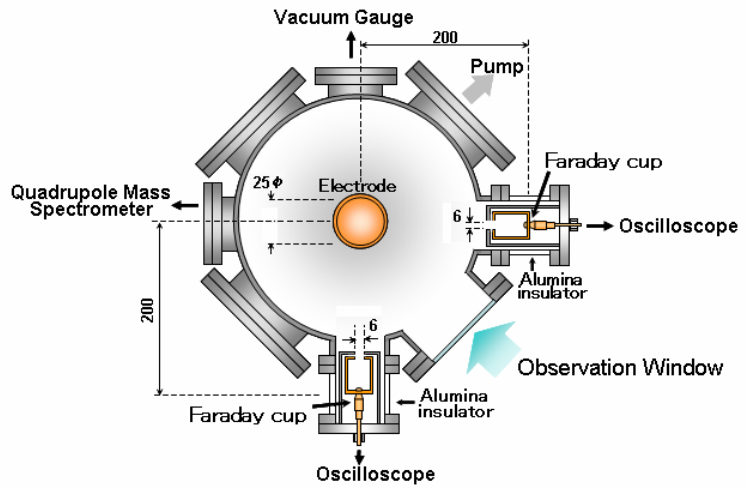

(b) Cross section view

Fig. 1. Experimental setup.

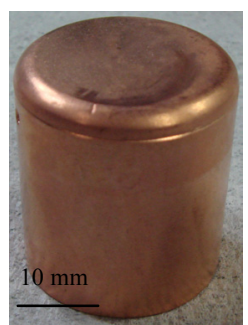

(a) Oxygen-free copper

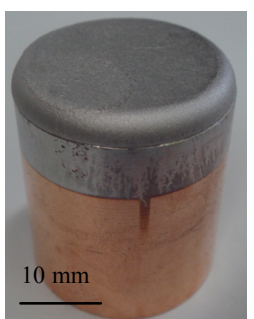

(b) $\mathrm{CuCr}(50: 50)$
Fig. 2. Test electrodes.
制御することで，電極の開閉動作を行う。電極の開極速度 は $0.8 \mathrm{~m} / \mathrm{s}$ であり, 開極後の電極間のギャップ長は $3 \mathrm{~mm}$ に 設定している。

〈2·2〉実験回路 実験回路は Fig.3 に示すように $L C$ 共振式大電流発生回路と $R C$ 小電流回路から成っている。 $R C$ 小電流回路は同図右側部で時定数が $0.24 \mathrm{~s}$ の減衰波形で ある。スイッチ VS1 を閉じることにより減衰電流を通電し ておき，電極を開極することにより真空アークを発生させ る。電極の開極が完了した後, 同図左側部の $L C$ 共振回路の スイッチVS2 を閉じることで供試電極に約 $50 \mathrm{~Hz}$ の交流大 電流を投入し，大電流アークを発生できる。このとき，ス イッチ VS4 を電流零点前に開極することでシャント抵抗 (Shunt1) に電流を転流し, 電流零点後の遮断失敗に備えて スイッチ VS5 を閉極しシャント抵抗 (Shunt1) の焼損を防 いでいる。

$\langle 2 \cdot 3\rangle$ 荷電粒子測定真空アークから拡散してくる 荷電粒子の測定では，電子とイオンを同時に測定するため に Fig.1(b)のように配置したファラデーカップを 2 個用いて いる。各ファラデーカップの開口部は直径 $6 \mathrm{~mm}$ で, アーク 発生点から $200 \mathrm{~mm}$ の位置に設置され, 真空容器から絶縁さ れている。また, ファラデーカップに入射した荷電粒子の 散乱や 2 次電子放出などによる見かけ上の電流值が変化し ないように，ファラデーカップはカップ状の構造になって いる。本実験において, 各ファラデーカップには+30 V と - $100 \mathrm{~V}$ のバイアス電圧を印加することで, 電子とイオンを 選別して測定できるようになっている。また，ファラデー カップを接地電位のステンレス鋼製のカバーで覆うこと で, 真空容器などに衝突・散乱してファラデーカップに飛 散してくる荷電粒子を遮蔽し，真空アークからビーム状に 拡散する荷電粒子のみを測定対象とすることができるよう にしている。また, 荷電粒子電流の測定では, ファラデー カップの配置と陰極上のカソードスポットの位置によって は，その電流值が変わることがある。一方で，カソードス ポットは陰極上をランダムに動き, 且つ実験毎にその発生 場所も異なる。そこで本測定ではファラデーカップのバイ アス電圧を実験毎に入れ換えてデータを複数回取得して

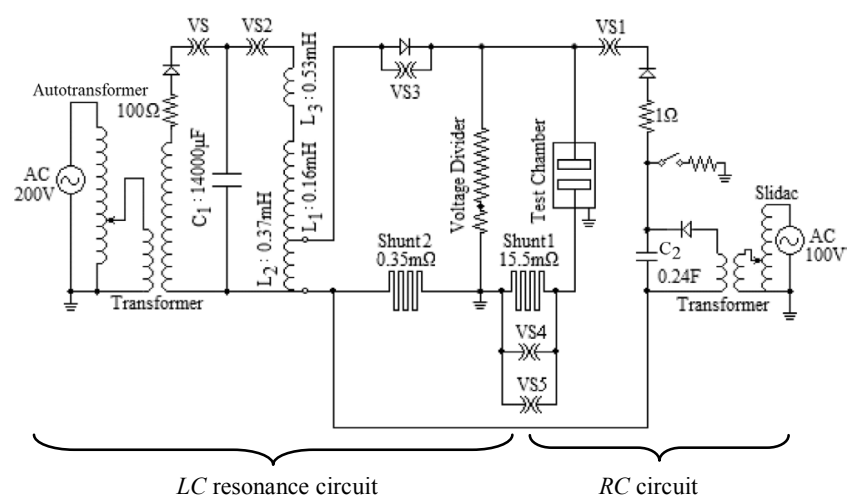

Fig. 3. Combination circuit of $L C$ resonance circuit generating $\mathrm{AC}$ high current and $R C$ circuit generating DC-line current. 
いる。

〈2·4〉実験方法 本研究では, まず $R C$ 小電流回路の みを使用し, 無酸素銅電極について, 100 A 150 A の真空ア 一ク発生時の荷電粒子電流の測定を行った。次に, 無酸素 銅電極および $\mathrm{CuCr}$ (含有率 $\mathrm{Cu}: \mathrm{Cr}=50: 50$ ) 電極について，波 高值 2,000 A 10,000 A の $L C$ 共振電流を真空アーク発生装置 に流し, 交流大電流の真空アーク発生時において, 電流零 点前の荷電粒子電流の測定を行った。

実験では, アーク電流をシャント抵抗で, アーク電圧（極 間電圧）を分圧器で，荷電粒子電流をファラデーカップで それぞれ測定している。また，高速度ビデオカメラを用い て, フレーム速度 $1 / 73,000 \mathrm{~s}$ で真空アーク現象の観測も行っ た。なお，ロータリーポンプおよびターボ分子ポンプは真 空アーク発生時も排気している。真空アークの実験は，実 験毎に数分間間隔を空けて, 真空容器内の圧力が $10^{-5} \mathrm{~Pa}$ 程 度に落ち着くまで待ってから実験を行った。

\section{3. 実験結果および考察}

\section{$\langle 3 \cdot 1\rangle R C$ 減衰小電流における荷電粒子電流の測定}

構築した測定系で荷電粒子が測定できているか評価する ために, 供試電極材料に無酸素銅電極を用いて $R C$ 小電流回 路により約 $100 \mathrm{~A}$ の真空アークを発生させた場合について 荷電粒子電流の同時測定を行った。Fig.4に $100 \mathrm{~A}$ の小電流 アーク発生時のアーク電流，アーク電圧（極間電圧）およ び荷電粒子電流波形を示す。同図(a)の電流波形からわかる ように, 電流は約 $50 \mathrm{~ms}$ の時点から $R C$ 小電流回路によって 約 $105 \mathrm{~A}$ が流れている。なお， $50 \mathrm{~ms}$ から $65 \mathrm{~ms}$ までは，電 極は閉じた状態であるため, 電極間に真空アークは発生し ていない。電極の開極動作は $65 \mathrm{~ms}$ の時点で開始し，開極と 同時に約 $20 \mathrm{~V}$ のアーク電圧が発生している。それと同時に イオン電流と電子電流がファラデーカップにより測定され ている。これらイオンや電子の荷電粒子電流波形から，真 空アークから拡散してくるイオンや電子はパルス状にファ ラデーカップに入射していることがわかる。また，それら の電流值は，アーク電流值との相関もあるように見える。 同図(b)は, 同図(a)の約 $115 \mathrm{~ms}$ 付近 $100 \mu \mathrm{s}$ 間を拡大したもの である。同図より荷電粒子電流は脈動しており，そのパル ス間隔は $1 \sim 10 \mu \mathrm{s}$ 程度であることがわかる。これは陰極点の 存続時間 ${ }^{(3)}$ に対応しており，陰極点は隣接部へ発生・消滅を 繰り返しながら移動していることと対応している。また, イオン電流值と電子電流值を比較すると, 電子電流がイオ ン電流より 2 桁程度大きいことがわかるが，これは陰極点 から放出される正イオン, 中性金属蒸気および電子数の発 生割合が 1:10:100 であるという報告(4) とほぼ一致している。 Fig.4(c)に同図(b)の拡大波形の区間における高速度ビデオカ メラで撮影した陰極側の電極上のアーク画像を示す。同図 (c)は約 $30 \mu \mathrm{s}$ 毎の連続画像である。同図より電極上に陰極点 を 1 つ確認することができる。この陰極点は電極面上をラ ンダムに移動しており，同図(c)では時間経過とともに陰極 点の明るさが変化しているのが確認できる。

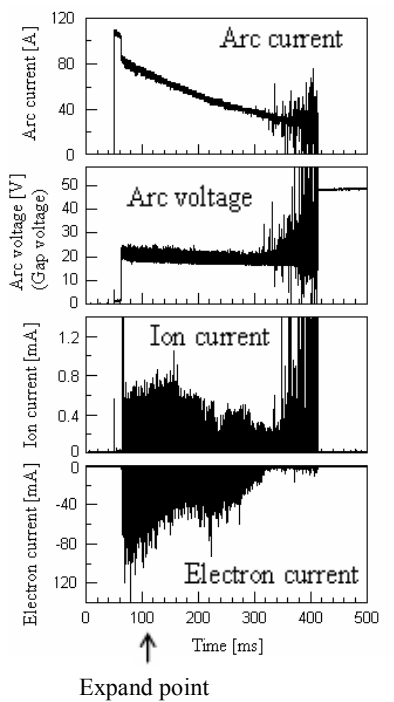

(a) Full scale

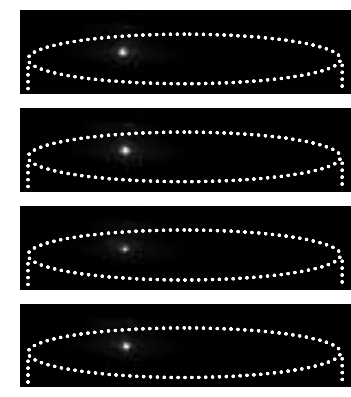

$114.898 \mathrm{~ms}$

$114.925 \mathrm{~ms}$

$114.953 \mathrm{~ms}$

(c) Vacuum arc images (Frame rate $=1 / 73,000 \mathrm{fps}$ )

Fig. 4. Arc current waveform, arc voltage waveform, charged particle current waveform and images of cathode spots; Electrode material: Oxygen-free copper, Current: DC 100 A.

\section{$\langle 3 \cdot 2\rangle \quad$ 交流大電流における荷電粒子電流の測定}

無酸素銅電極について, 前節の $R C$ 減衰小電流を流して真 空アークを発生させてから, 続けて波高值約 4,000 A の $L C$ 共振電流を流寸。交流大電流の真空アーク発生時において の荷電粒子電流の測定を行った。Fig.5(a)に交流大電流アー ク発生時のアーク電流，アーク電圧（極間電圧）を示す。 同図においては，電流波形の縦軸のスケールの関係で小電 流はほとんど確認できないが, 約 $6 \mathrm{~ms}$ の時点から $100 \mathrm{~A}$ 程 度の小電流が電極間に流れている。電極は約 $19 \mathrm{~ms}$ 時に開極 しており，それと同時に約 $20 \mathrm{~V}$ 程度のアーク電圧が発生し ている。 $L C$ 共振電流は約 $40 \mathrm{~ms} 50 \mathrm{~ms}$ にかけて流れており, その間，アーク電圧は若干上昇している。Fig.5(b)は同図(a) の約 $50 \mathrm{~ms}$ 付近 $100 \mu \mathrm{s}$ 間の荷電粒子電流波形を含めた拡大 図である。また，Fig.5(c)に拡大波形の区間における約 $30 \mu \mathrm{s}$ 毎のアーク画像を示す。Fig.5(b)より荷電粒子電流波形は,

Fig.4(b)の 100 A 小電流アーク発生時と同様に脈動を伴って いるのが確認できる。また，イオン電流，電子電流ともア 一ク電流の減少に伴いながら減少する傾向にある。それら の電流波形のパルスとパルスの間の電流值は, Fig.4(b)の荷 電粒子電流と比較すると多くなっている。これは Fig.5(c)で 


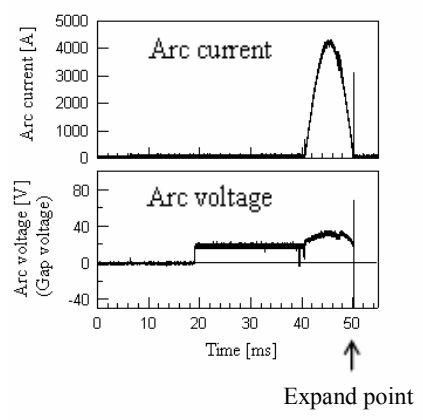

(a) Full scale

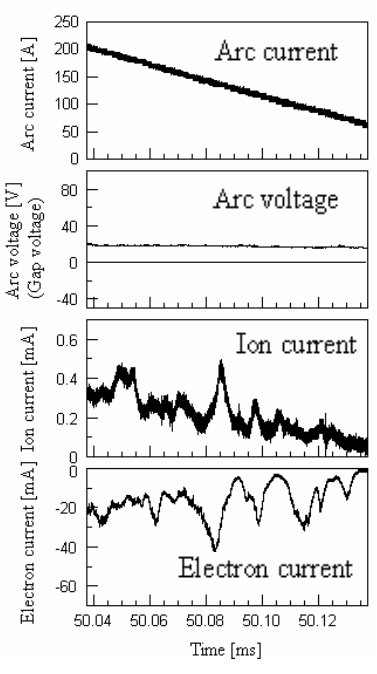

(b) Expand point

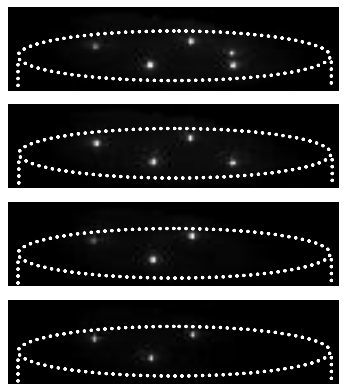

$50.038 \mathrm{~ms}$

$50.066 \mathrm{~ms}$

$50.094 \mathrm{~ms}$

$50.121 \mathrm{~ms}$

(c) Vacuum arc images (Frame rate $=1 / 73,000 \mathrm{fps}$ )

Fig. 5. Arc current waveform, arc voltage waveform, charged particle current waveform and images of cathode spots; Electrode material: Oxygen-free copper, Current: AC 4,000 A.

確認できるように陰極点が複数個現れるため，陰極点が 1 個しか現れていない $100 \mathrm{~A}$ アークの場合に比べて, 荷電粒子 電流波形はそれぞれの陰極点から放出されるイオンや電子 が重ね合わさった波形になっているためと考えられる。

\section{$\langle 3 \cdot 3\rangle \quad$ 交流大電流零点前の荷電粒子電流の測定}

無酸素銅電極および $\mathrm{CuCr}$ (含有率 $\mathrm{Cu}: \mathrm{Cr}=50: 50$ ) 電極につ いて, 波高值 2,000 A 10,000 A の交流大電流の真空アーク発 生時における電流零点近傍における荷電粒子電流の測定を 行った。Fig.6(a)に無酸素銅電極，Fig.7(a)に $\mathrm{CuCr}$ 電極にお ける電流波高值約 8,000 A 交流アーク発生時のアーク電流, アーク電圧（極間電圧）をそれぞれ示す。また，各図(b)は 電流零点前においてアーク電流の平均值が $50 \mathrm{~A}$ となる区間 $25 \mu \mathrm{s}$ のアーク電流，アーク電圧（極間電圧）および荷電粒 子電流波形である。各図(c)は，各図(b)の区間近傍の約 $14 \mu \mathrm{s}$ 毎のアーク画像である。Fig.6(c)の無酸素銅電極の連続アー ク画像より, 電流平均 $50 \mathrm{~A}$ となる区間の陰極点はほとんど が 1 個であるのに対して, $\mathrm{CuCr}$ 電極の場合, Fig.7(c)の連続 アーク画像より，無酸素銅電極と同じ平均電流にもかかわ らず陰極点は多数現れた。このような傾向は，波高值 2,000 A 10,000 A の全ての場合において確認された。

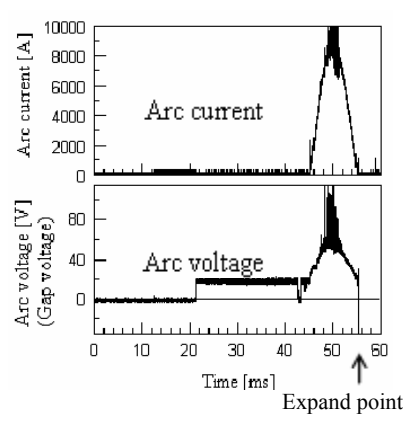

(a) Full scale

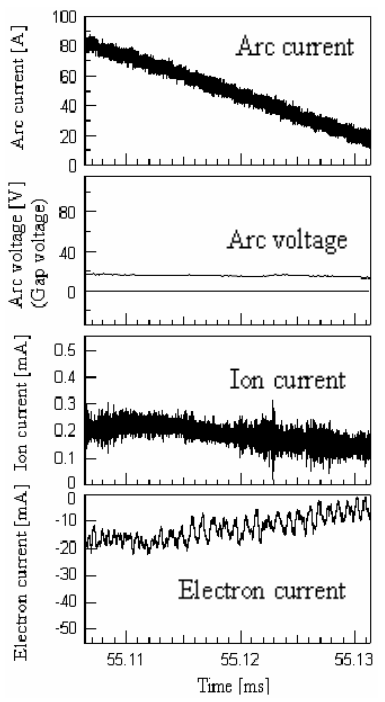

(b) Expand point

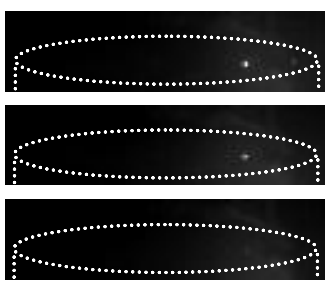

$55.109 \mathrm{~ms}$

$55.123 \mathrm{~ms}$

$55.137 \mathrm{~ms}$

(c) Vacuum arc images (Frame rate $=1 / 73,000 \mathrm{fps}$ )

Fig. 6. Arc current waveform, arc voltage waveform, charged particle current waveform and images of cathode spots; Electrode material: Oxygen-free copper, Current: AC 8,000 A.

Fig.8 に Fig.6(b), Fig.7(b)のそれぞれの区間におけるイオ ン電流, 電子電流の平均值とアーク電流波高值との関係を 無酸素銅電極および $\mathrm{CuCr}$ 電極について示す。ここで, Fig.8 の横軸は交流電流の波高值である。同図より, $\mathrm{CuCr}$ 電極に ついては電流波高值の増加に伴ってイオン電流および電子 電流の值が増加する傾向にあることがわかる。しかし, 無 酸素銅電極については $\mathrm{CuCr}$ 電極ほどイオン電流, 電子電流 の值が増加する傾向は見られない。Fig.8 からアーク電流の 波高值と電子電流およびイオン電流の相関係数は, イオン 電流について無酸素銅電極で $0.12, \mathrm{CuCr}$ 電極で 0.55 であり, 電子電流については無酸素銅電極で $0.10, \mathrm{CuCr}$ 電極につい ては 0.74 であった。このことからも無酸素銅電極において は電流波高值とイオン電流や電子電流に相関がほとんど無 いことがわかる。Fig.9 にイオン電流と電子電流の比とアー ク電流波高值との関係を示す。同図から両電極ともに電流 波高值に対して大きな依存はなく, およそ $0 \sim 0.02$ の範囲に 存在していることがわかる。

Fig.10に $\mathrm{CuCr}$ 電極における遮断失敗時のアーク電流, ア 一ク電圧 (極間電圧), 荷電粒子電流波形および拡大波形の 区間近傍のアーク画像を示す。Fig.10(b)よりイオン電流およ び電子電流波形は, Fig.6(b)や Fig.7(b)の荷電粒子電流波形同 様，アーク電流とともに減少しているのがわかる。 


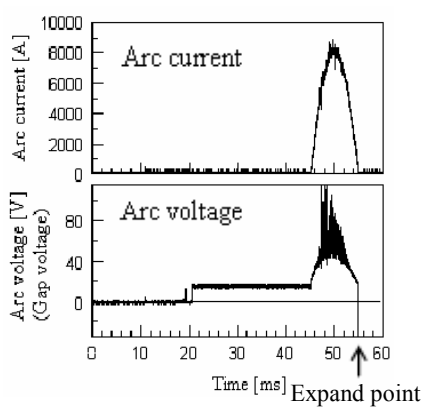

(a) Full scale

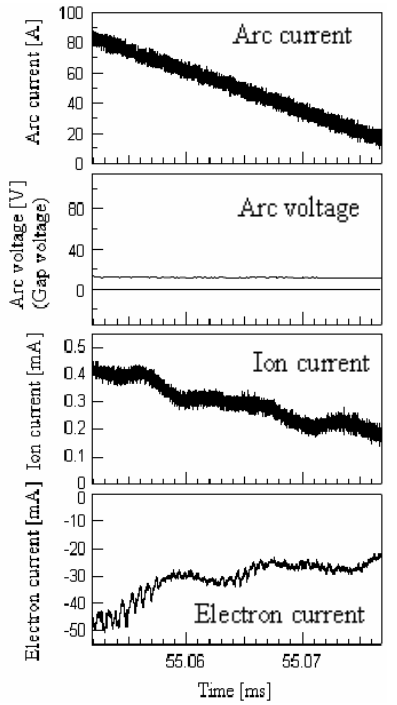

(b) Expand point

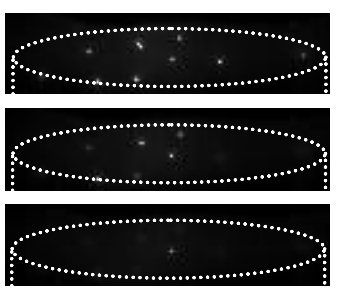

(c) Vacuum arc images (Frame rate $=1 / 73,000 \mathrm{fps}$ )

Fig. 7. Arc current waveform, arc voltage waveform, charged particle current waveform and images of cathode spots; Electrode material: CuCr, Current: AC 8,000 A.

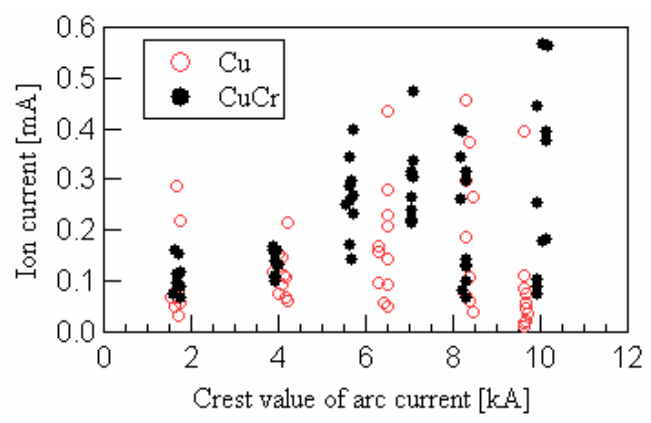

(a) Ion current

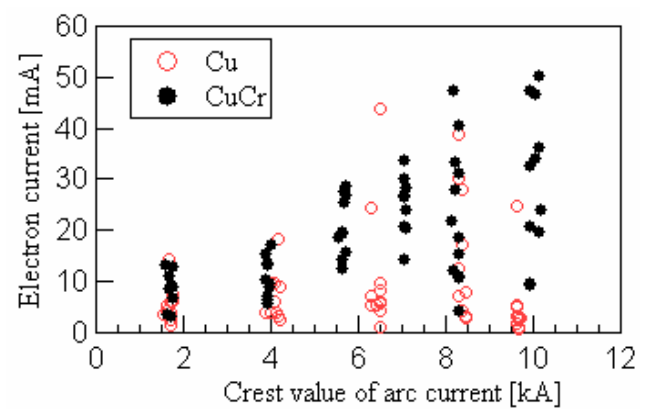

(b) Electron current

Fig. 8. Dependence of charged particle current on arc current.

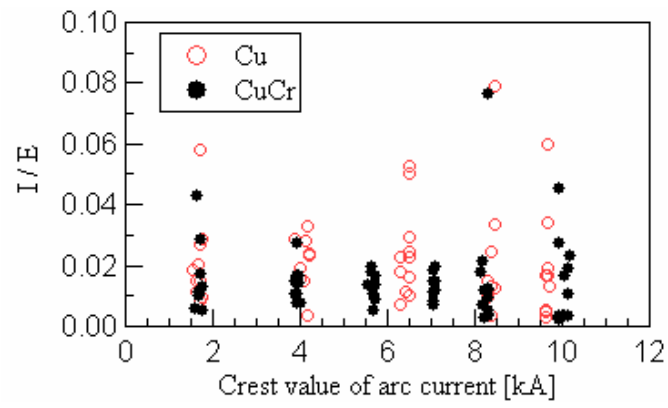

Fig. 9. Dependence of $I / E$ on arc current.

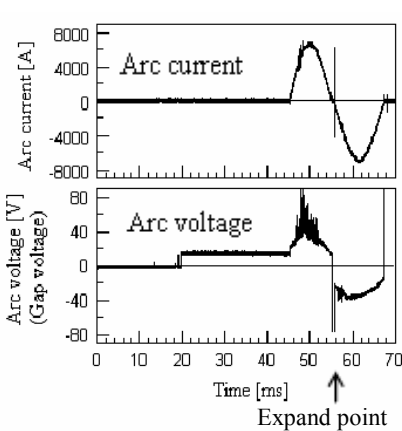

(a) Full scale

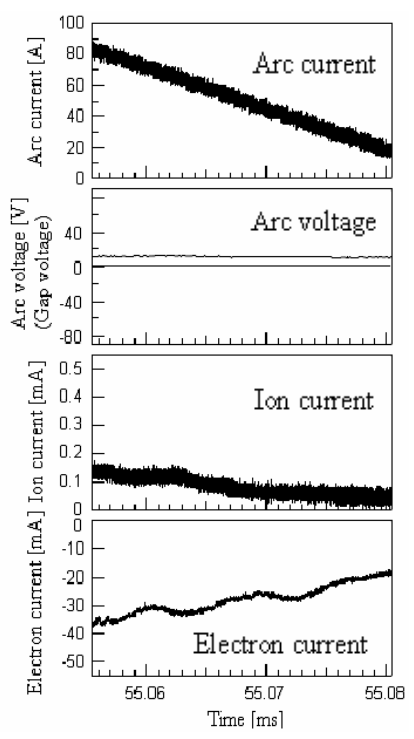

(b) Expand point

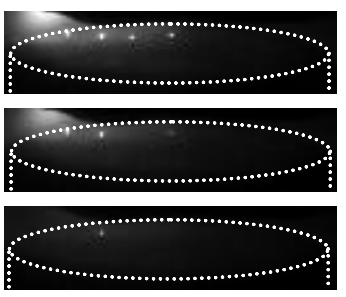

$55.056 \mathrm{~ms}$

$55.070 \mathrm{~ms}$

$55.083 \mathrm{~ms}$
Fig. 10. Arc current waveform, arc voltage waveform, charged particle current waveform and images of cathode spots for the case of interruption failure; Electrode material: $\mathrm{CuCr}$, Current: AC 8,000 A.

Fig.11 に Fig.8 および Fig.9 で示した荷電粒子電流，イオ ン電流と電子電流の比のアーク電流依存性について, 遮断 失敗のデータを別サンプルとして分けた結果を示す。Fig.11 より両電極について遮断失敗の結果を見てみると, イオン 電流, 電子電流ともに遮断成功の結果と大きな相違はなく, 点在しているのがわかる。イオン電流と電子電流の比につ いても同様に，特別な傾向があるようには思われない。ま た, 今回の測定では無酸素銅電極に比べて $\mathrm{CuCr}$ 電極での遮 断失敗が多かった。 


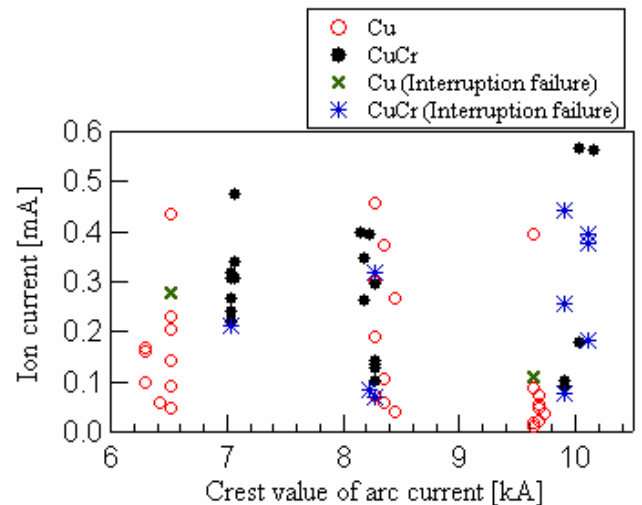

(a) Ion current

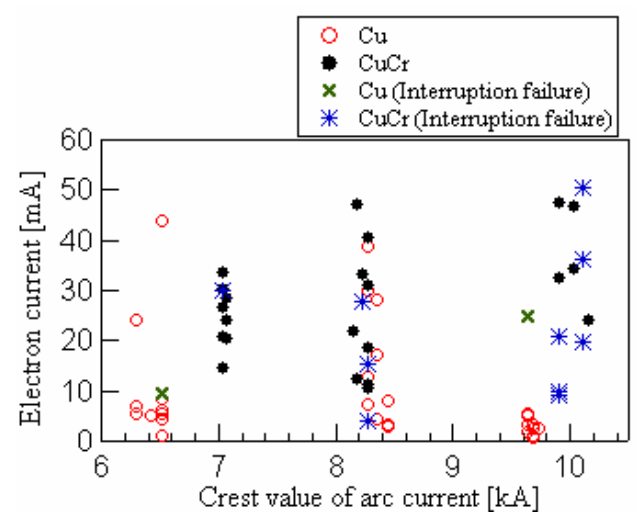

(b) Electron current

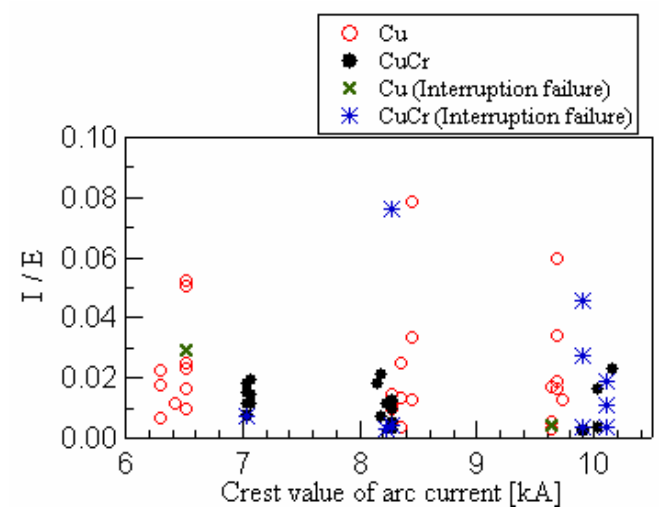

(c) $I / E$

Fig. 11. Dependence of charged particle current and $\mathrm{I} / \mathrm{E}$ on arc current for the case of interruption failure.

\section{4. まとめ}

本研究では荷電粒子測定系を構築し，真空アークから拡 散する荷電粒子の測定を行った。電子やイオンはパルス状 にファラデーカップに入射しており，その間隔は $1 \sim 10 \mu \mathrm{s}$
で，これは陰極点の挙動を表していると考えられる。また， 交流大電流零点前の荷電粒子電流の測定を行った結果, $\mathrm{CuCr}$ 電極については, 電流波高值の増加に伴い荷電粒子電 流の值が増加する傾向にあることがわかったが，無酸素銅 電極については大きな増加の傾向は見られなかった。イオ ン電流と電子電流の比とアーク電流值との関係について は，両電極ともに電流波高值に大きな依存はなく，0 0.02 の範囲に存在していることがわかった。

(平成 22 年 1 月 18 日受付，平成 22 年 5 月 18 日再受付)

文献

（1）小山健一・中山 靖・木村俊則・笹尾博之:「レーザー誘起蛍光法を 用いた真空アークの粒子計測」, 平成 10 年電気学会全国大会, pp.S4-17.4-20 (1998)

（2）石橋一成・鈴木伸輔・柳父 悟: 「電極構造の違いによる真空アーク 中のイオン電流の角度分布測定」, 平成 15 年電気学会電力・エネル ギー部門大会, pp.139-140 (2003)

(3) 電気学会編: 「真空中での放電の利用とその抑制」, 技術報告, No.586, pp.33-45 (1996)

(4) 電気学会編: 「高エネルギー密度化に関わる真空中の放電制御技術」, 技術報告，No.1001, p.12, pp.41-43, pp.69-71 (2005)

觸 澤 将 倫 （学生員） 1985 年 6 月生。 2008 年 3 月埼玉大

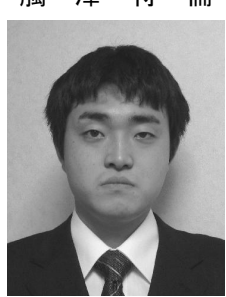
学卒業。同年 4 月同大学理工学研究科博士前期 課程入学, 現在に至る。主に真空アークから拡 散する荷電粒子の測定に関する研究に従事。

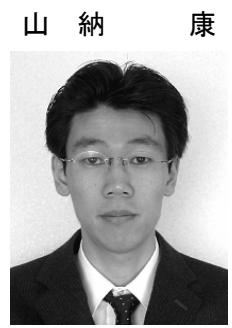

（正員） 1970 年 6 月生。1996 年 3 月名古屋工 業大学大学院工学研究科博士前期過程修了。同 年 4 月三菱重工業（株）入社。1998 年 4 月名古 屋大学大学院博士後期過程入学, 2000 年 3 月同 大学院修了。2000 年 4 月埼玉大学工学部助手, 2009 年同准教授。現在に至る。IEEE，日本真空 協会会員。

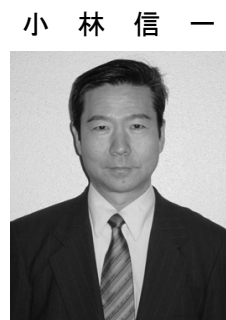

正員） 1947 年 4 月生。1969 年 3 月埼玉大学 理工学部卒業。1972 年 3 月東京農工大学工学研 究科修了。同年富士電機製造（株）入社。1989 年埼玉大学工学部助教授, 1994 年同教授。1994 年英アストン大学客員研究員。工学博士。真空 中の高電圧絶縁破壊現象に関する研究関連技 術開発に従事。 